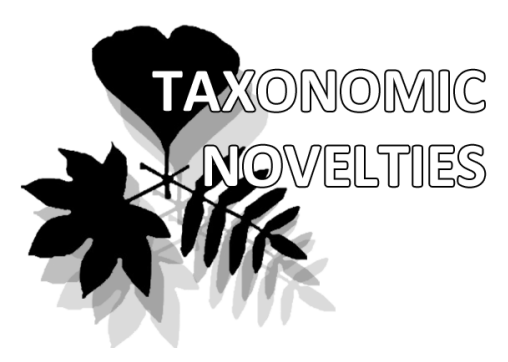

Vadim A. Bakalin

e-mail: vabakalin@gmail.com

Anna A. Vilnet ${ }^{2}$

e-mail: anya_v@list.ru

${ }^{1}$ Botanical Garden-Institute FEB RAS, Vladivostok, Russia

${ }^{2}$ Polar-Alpine Botanical Garden-Institute of the Kola Science Center of RAS, Kirovsk, Russia

* corresponding author

Manuscript received: 01.11.2017 Review completed: 20.11.2017 Accepted for publication: 21.11.2017

Published online: 28.11.2017

\section{A new large-celled species of Plagiochila (Plagiochilaceae, Hepaticae) from the southern flank of the Russian Far East}

\author{
Vadim A. Bakalin ${ }^{1 *} \&$ Anna A. Vilnet ${ }^{2}$
}

\begin{abstract}
A B S T R A C T
A new species of Plagiochila is described from cool-temperate Ussuri taiga zone in the Russian Far East using integrative morphological and molecular-genetic approach. Plagiochila sichotensis Bakalin et Vilnet sp. nov. (sect. Plagiochila) is characterized by totally entire leaves, relatively small size and, particularly, very large midleaf cells reaching $40-60 \mu \mathrm{m}$ wide in the leaf middle. The latter feature distinguishes the new species from all known taxa of the genus and, among regional taxa, somewhat similar to the not evolutionary related Mylia. This epixylous taxon seems to be confined in its distribution to the low to middle elevation of mountains in the southern Sikhote-Alin Mts. The description, illustrations and discussion on the new species are provided.
\end{abstract}

Ke y w o r d s : Plagiocbila, Hepaticae, the Russian Far East, taxonomy, flora

\section{PE 3 Ю ME}

Бакалин В.А., Вильнет А.А. Новый крупноклеточный виА Plagiochila (Plagiochilaceae, Нераticae) с южной окраины российского Аальнего Востока. Новый виА Plagiochila описан из Уссурийской тайги, располагающейся на юге российского Аальнего Востока. Plagiochila sichotensis Bakalin et Vilnet sp. nov. (sect. Plagiochila) характеризуется цельными Аистьями, относительно мелкими размерами и, в особенности, крупными клетками мистьев, Аостигающими в середине листа 40-60 мкм ширины. Последний признак отличает новый вид от всех известных таксонов рода и близок к значениям, наблюдаемым в эволюционно неродственном роде Mylia. По-видимому, этот эпиксильный таксон ограничен в распространении нижним и средним высотными поясами гор Сихотэ-А^иня. Приводятся описание, илАюстрации и отАичительные признаки нового виАа.

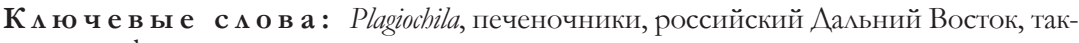
сономия, фмора
Several years ago one of the authors (VB) collected small plagiochiloid plants that were tentatively named as Pedinophyllum sp. due to the size, contiguous to enclosed one to another leaves, entire female bracts and dense mat of rhizoids. However, as it was noted even at the time of collections, the plants possess densely ciliate perianth mouth that suggested Plagiochila. Later, in laboratory studies another unique feature was found in the leaf cells those were extremely large (both for Plagiocbila and Pedinophyllum) and reached $40-60 \mu \mathrm{m}$ wide in the midleaf that made possible relationships with Mylia even, with which the collected plants were also similar in leaf position and orientation. The specimen was kept under Pedinophyllum until recently when it was involved into molecular study that undoubtedly showed the plants belong to the Plagiocbila. The plants were attended to the new taxon; to describe the latter is the main goal of the present account.

\section{Materials and Methods}

Originally the specimens were microscopied and compared with other taxa of regional Plagiochilaceae using morphological method. After exceedingly large-sized midleaf cells were observed and because of uncertainty of generic position of the plants the molecular comparison was conducted using standard protocols. DNA was extracted from dried liverwort tissue using the NucleoSpin Plant Kit (Macherey-Nagel, Germany). The amplification and sequencing were performed using primers suggested by White et al. (1990) for ITS1-2, Kress \& Erickson (2007) for rbcL, respectively. PCR were carried out in $20 \mu \mathrm{l}$ volumes with the following amplification cycles: 3 min at $94^{\circ} \mathrm{C}, 30$ cycles $(30 \mathrm{~s}$ $94^{\circ} \mathrm{C}, 40 \mathrm{~s} 56^{\circ} \mathrm{C}, 60 \mathrm{~s} 72^{\circ} \mathrm{C}$ ) and 2 min of final extension time at $72^{\circ} \mathrm{C}$. Amplified fragments were visualized on $1 \%$ agarose TAE gels by EthBr staining, purified using the GFX PCR DNA and Gel Band Purification Kit (Amersham Biosciences, U.S.A.), and then used as a template in sequencing reactions with the ABI Prism BigDye Terminator Cycle Sequencing Ready Reaction Kit (Applied Biosystems, USA) following the standard protocol provided for 3100 Avant Genetic Analyzer (Applied Biosystems, USA).

We used BLAST search (http://blast.ncbi.nlm.nih.gov/ Blast.cgi) to distinguish the group of closely related species to sequenced specimen and then produced dataset to test it phylogenetic affinity (accession numbers are shown in Table 1). The ITS1-2 and $r b c \mathrm{~L}$ nucleotide sequences were automatically aligned in BioEdit 7.0.1 (Hall 1999) with Clus- 
Table 1. The list of taxa, specimens vouchers and GenBank accession numbers, accessions obtained in this study are in bold

\begin{tabular}{llcc}
\hline Taxon & Specimen voucher & \multicolumn{2}{c}{ GenBank accession numbers } \\
\cline { 2 - 3 } & & ITS1-2 & rbcL \\
\hline Plagiochila asplenioides & Italy, Schaefer-Verwimp \& Verwimp, 35859 (M) & KT992544 & KT992617 \\
Plagiochila britannica & United Kingdom, Rycroft 00015, B.E.G.P. 199 (GOET) & AY275162 & DQ194119 \\
Plagiochila elegans & China, Long 33675 (GOET) & AM180599 & No data \\
Plagiochila flexuosa & Japan, Kurita 147 (HIRO) & AY550138 & DQ194140 \\
Plagiochila hakekodensis & Japan, Yamaguchi 12271 (HIRO) & AY275164 & DQ194149 \\
Plagiochila korthalsiana & Indonesia: Mt. Gedeh, Java, Gradstein 10258 & DQ194049 & DQ194156 \\
Plagiochila orbicularis & Japan, Kurita 132 (HIRO) & AY275168 & DQ194167 \\
Plagiochila ovalifolia & Japan, Ohnishi 5723 (HIRO) & AY275169 & No data \\
Plagiochila porelloides & Portugal, Schaefer-Verwimp, 31246 (M) & KT992543 & KT992616 \\
Plagiocbila satoi & Japan, Ohnishi 5720 (HIRO) & AY550144 & DQ194192 \\
Plagiochila sichotensis & Russia: Primorsky Territory, Bakalin \& Arutinov, 1-25-13 (VBGI), 118477 (KPABG) & MF947695 & MF947696 \\
Plagiochila trapezoidea & Australia, 1, Renner, NSW855092 & KY051542 & KY051052 \\
Plagiochila trapezoidea & Australia, 2, Renner, NSW858922 & KY051543 & KY051053 \\
Plagiocbila trapezoidea & Australia, 3, Renner, NSW858927 & KY051544 & KY051054 \\
Plagiocbila trapezoidea & Australia, 4, Renner, NSW897031 & KY051545 & KY051055 \\
\hline
\end{tabular}

talW option and then manually corrected. The preliminary phylogenetic analyses revealed topology congruence between both datasets and they were combined. All positions of the final alignment were included in the phylogenetic analysis, absent data was coded as missing. The combined ITS1-2 + rbcL alignment was analyzed only by the maximum likelihood method (ML) with PhyML v. 3.0 (Guindon et al. 2010) due to absence of $r b c \mathrm{~L}$ nucleotide sequences for two specimens. The TN+I model was selected as the best-fit evolutionary model of nucleotide substitutions for alignment using the ModelGenerator software (Keane et al. 2004). In ML analysis this model was used and the rate heterogeneity among sites was modeled using a gamma distribution with four rate categories. Bootstrap support (BS) for individual nodes was assessed using a resampling procedure with 500 replicates. According to the stopping frequency criterion (FC) for bootstrapping procedure (Pattengale et al. 2010) for our dataset only 350 replicates were enough for reaching BS convergence with Pearson average $\varrho 100=0.994474$ as estimated by RAxML v. 7.2.6 (Stamatakis 2006). The calculation of genetic distances (p-distances) was provided with Mega 5.1 (Tamura et al. 2011) to characterize the level of species divergence, obtained results are shown in Table 2.

\section{RES U LT S}

The ITS1-2 and $r b c \mathrm{~L}$ nucleotide sequences for studied Plagiochila specimen were obtained and deposited in GenBank. BLAST search revealed similarity of tested specimen with species from sect. Plagiochila in 96-97\% by ITS1-2 and 98-99 \% by rbcL. Based on previous phylogenetic studies on the genus Plagiochila (Patzak et al. 2016, Renner et al. 2017) for our analysis we selected 10 species (13 specimens) of sect. Plagiochila and P. flexuosa (sect. Trabeculatae S. Hatt. ex Inoue) as outgroup taxon and downloaded their ITS1-2 (14 accessions) and $r b c \mathrm{~L}$ (12 accessions) nucleotide sequences from GenBank. The combined ITS1-2+rbcL alignment for 15 specimens consists of 1469 character sites, among them 828 sites belong to ITS1-2 and 641 sites - to $r b c \mathrm{~L}$. The number of invariable sites in ITS1-2 and $r b c \mathrm{~L}$ are $716(86.47 \%)$ and $606(94.54 \%)$, variable positions are $98(11.84 \%)$ and $35(5.5 \%)$, parsimony informative positions are 35 (4.22\%) and $15(2.3 \%)$. In the combined alignment there are 1322 (90.0\%) invariable sites, $133(9.1 \%)$ variable and 50 (3.4\%) parsimony informative positions.

The ML calculation resulted in a tree with Log likelihood of -3022.68394 , the obtained tree topology is shown on Fig. 1 with indication of bootstrap support values (BS).

Table 2. The value of infrageneric p-distances ITS1-2 /rbcL, \% for the section Plagiochila. '-' - non calculated value due to absence of DNA locus

\begin{tabular}{|c|c|c|c|c|c|c|c|c|c|c|c|c|}
\hline \multirow{2}{*}{$\frac{\text { Species }}{\text { porelloides }}$} & \multirow[t]{2}{*}{ porelloides } & \multirow[t]{2}{*}{ britannica } & \multirow[t]{2}{*}{ satoi } & \multirow[t]{2}{*}{ bakkodensis } & \multirow[t]{2}{*}{ ovalifolia } & \multicolumn{3}{|c|}{ korthalsiana asplenioides orbicularis } & \multirow[t]{2}{*}{ sichotensis } & \multirow[t]{2}{*}{ elegans } & \multirow{2}{*}{\multicolumn{2}{|c|}{ trapezoidea flexuosa }} \\
\hline & & & & & & & & & & & & \\
\hline britannica & $0.1 / 0.5$ & & & & & & & & & & & \\
\hline satoi & $0.3 / 0.2$ & $0.3 / 1.1$ & & & & & & & & & & \\
\hline hakekodensis & $1.1 / 0.7$ & $1.1 / 1.1$ & $0.9 / 1.2$ & & & & & & & & & \\
\hline ovalifolia & $1.2 /-$ & $1.2 /-$ & $0.9 /-$ & $1.0 /-$ & & & & & & & & \\
\hline korthalsiana & $1.4 / 1.5$ & 1.4/1.6 & $1.3 / 1.7$ & $1.1 / 1.7$ & $1.4 /-$ & & & & & & & \\
\hline asplenioides & $1.4 / 0.7$ & $1.5 / 0.2$ & $1.3 / 1.0$ & $1.2 / 1.0$ & $1.2 /-$ & $1.5 / 1.1$ & & & & & & \\
\hline orbicularis & $1.1 / 0.7$ & $1.1 / 0.5$ & $0.9 / 0.9$ & $1.1 / 0.9$ & $1.1 /-$ & $1.5 / 1.1$ & $1.4 / 0$ & & & & & \\
\hline sichotensis & $2.0 / 1.0$ & $1.9 / 2.0$ & $2.2 / 1.4$ & $2.1 / 2.2$ & $2.6 /-$ & $2.7 / 2.7$ & $2.7 / 1.9$ & $2.2 / 1.9$ & & & & \\
\hline elegans & $3.5 /-$ & $3.6 /-$ & $3.4 /-$ & $3.5 /-$ & $3.8 /-$ & $3.5 /-$ & $3.9 /-$ & $3.5 /-$ & $3.8 /-$ & & & \\
\hline trapezoidea & $3.5 / 2.2$ & $3.6 / 1.9$ & $3.4 / 2.4$ & $3.8 / 2.2$ & $3.9 /-$ & $3.5 / 2.3$ & $4.2 / 1.7$ & $3.7 / 1.7$ & $4.4 / 3.0$ & $3.8 /-$ & & \\
\hline flexuosa & $5.6 / 1.7$ & $5.7 / 1.7$ & $5.7 / 1.6$ & $5.8 / 1.9$ & $6.0 /-$ & $5.6 / 2.3$ & $5.7 / 1.6$ & $5.3 / 1.6$ & $6.6 / 1.9$ & $6.4 /-$ & $5.9 / 1.6$ & \\
\hline
\end{tabular}




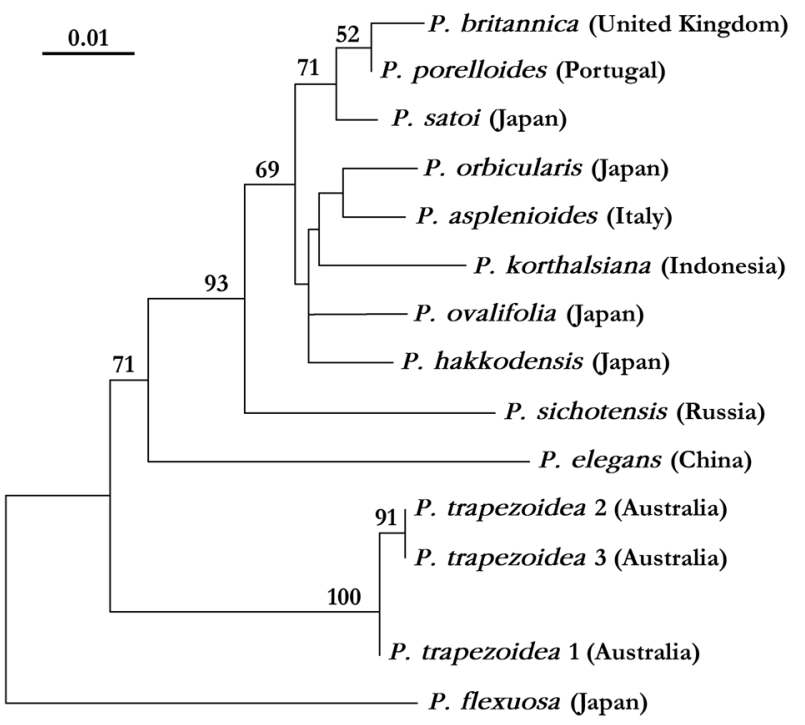

Figure 1 Phylogram obtained in a maximum likelihood calculation for the sect. Plagiochila based on combined nucleotide sequences dataset of ITS1-2 $n r \mathrm{DNA}$ and $r b c \mathrm{~L} c p \mathrm{DNA}$. Bootstrap support values more than $50 \%(0.50)$ are indicated

The phylogenetic affinity within sect. Plagiochila partially resembled those obtained by Patzak et al. (2016) and Renner et al. (2017), and the most of internal node still stayed without support. The newly sequenced Plagiochila specimen formed the basal branch to the clade of Circumboreal and East Asian Plagiochila (with the only exception for Java-Sumatra P. korthalsiana Molk. ex Sande Lac.) with $93 \%$ bootstrap support. The level of sequence divergence of tested specimen from species of aforementioned clade counts $1.9-2.7 \%$ in ITS1-2 and $1.0-2.7 \%$ in $r b c \mathrm{~L}$ that significantly exceed the level of species divergence within clade (0.1$1.5 \%$ in ITS1-2, $0.2-1.7 \%$ in $r b c \mathrm{~L}$, Table 2).

Therefore, no conspecific taxa from the sect. Plagiochila were found based on molecular approach. The morphological comparison with other Holarctic taxa of the section has revealed the robust difference of discussed plants from all known taxa in leaf cell size, leaf shape, position, margin features and rhizoid density along ventral side of the stem. Based on the evidences came from two sources (morphological and genetic), below we describe the discovered taxon as new species for science.

\section{Plagiochila sichotensis* Bakalin et Vilnet sp. nov.} Fig. 2, 3

Description. Plants loosely ascending in loose to relatively dense patches, bright to yellowish green and deep green, more or less rigid, 7-20 mm long, 2.5-3.2 mm wide. Stem sparsely and irregularly branched as lateral (rarely ventral) subfloral innovations and ordinary lateral branches, subfloral innovations commonly shortly (after each 4-5 mm) fertilized and perianthous again; stem yellowish brownish, leafless rhizome poorly developed, rhizogenous, produces ventral and lateral branches; stem cross section transversely elliptic, 270-350 $\mu \mathrm{m}$ wide and 250-325 $\mu \mathrm{m}$ high, outer layer composed by smaller than inner and with subequally thickened walls cells, trigones small to moderate in size, concave, inner layer cells 4-6-gonal, very thin-walled, with vestigial to small, concave trigones, $22-40 \mu \mathrm{m}$ in diameter. Rhizoids numerous, densely attaching plants to the substratum, in loose mat along ventral side of the stem, colorless to brownish-grayish. Leaves obliquely inserted, not or barely decurrent dorsally, contiguous, loosely sheathing the stem near base and spreading in upper half; when flattened in the slide ovate-lingulate to lingulate (large leaves), with rounded to truncate or shortly emarginate apex, $1.0-1.7 \times 1.2-1.7 \mathrm{~m}$, margin entire throughout. Cells in the midleaf subisodiametric to shortly oblong, 37-70 × 33-60 $\mu \mathrm{m}$, thin-walled, with moderate in size, convex trigones, with visible brownish median lamina; cells along leaf margin 32-45 $\mu \mathrm{m}$, thin-walled (external wall also thin), with moderate in size, concave to triangle convex trigones; cells near base oblong to shortly oblong, never 'vittate', 47-80 $\mu \mathrm{m}$ long; oil bodies 11-23 per midleaf cell, finely granulate, ellipsoidal to spherical. Dioicous? Androecia not seen. Perianth [only virtually mature perianths with unfertilized archegonia were observed], bilabiate, loosely laterally compressed, although in apical part closely contacted, shortly exerted, mouth with uniseriate cilia (1-)3-5(-6) cells long, cells 37-55 $\mu \mathrm{m}$ in length, with strongly thickened walls and large convex trigones; female bracts similar to large leaves, sheathing perianth in lower half and spreading above. Otherwise unknown.

Holotypus: RUSSIA. Primorye Territory, Shkotovsky District, Beryozovyy Stream, Picea-Abies-broadleaved deciduous forest in the stream valley, on decaying wood $\left(43^{\circ} 08^{\prime} 14^{\prime \prime} \mathrm{N} 132^{\circ} 47^{\prime} 51^{\prime \prime E}\right), 395 \mathrm{~m}$ alt., leg. V.A. Bakalin \& G. Arutiunov, 1-25-13 (VBGI, isotype in KPABG).

Paratypus: RUSSIA. Primorye Territory, Shkotovsky District, Ussurijsky Strict Nature Reserve, Zmeinaya Mt., broadleaved forest with admixture of Abies on N-facing slope, on decaying wood (433' $\left.43^{\prime \prime} \mathrm{N} 132^{\circ} 33^{\prime} 20^{\prime \prime} \mathrm{E}\right), 214 \mathrm{~m}$ alt., leg. V.A. Bakalin, P-64-2-08 (VBGI).

* - The epithet 'sichotense' comes from large mountain system name Sikhote-Alin ('Alin' = range) where the species was collected.

Ecology and distribution. The species is seems to be rarity in the flora of the southern flank of the Russian Far East. Despite distinctive appearance it was collected only twice since 2008 (when it was firstly discovered) although many field researches by several hepaticologists were organized in the land. Both localities lie in the spurs of the southern Sikhote-Alin Mountain system. Both are between low and middle elevation belts in cool-temperate communities belonging to so-called Ussuri taiga zone characterized by the mixture of conifers and broadleaved trees with common admixture of East Asian Taxus cuspidata Siebold et Zucc., Phellodendron amurense Rupr., Kalopanax septemlobus (Thunb.) Koidz. and shrubby Araliaceae. This contact zone of Circumboreal and East Asian biota is prominent by the distribution of several taxa of hepatics confined or primarily distributed there, like Mesoptychia ussuriensis (Bakalin) L. Söderstr. \& Váňa, Jungermannia konstantinovae Bakalin \& Vilnet, Plectocolea kurilensis (Bakalin) Bakalin \& Vilnet and Solenostoma pseudopyriflorum Bakalin \& Vilnet. The described Plagiochila sichotensis is one of the examples of the same series and may be regarded as the taxon probably preserved 


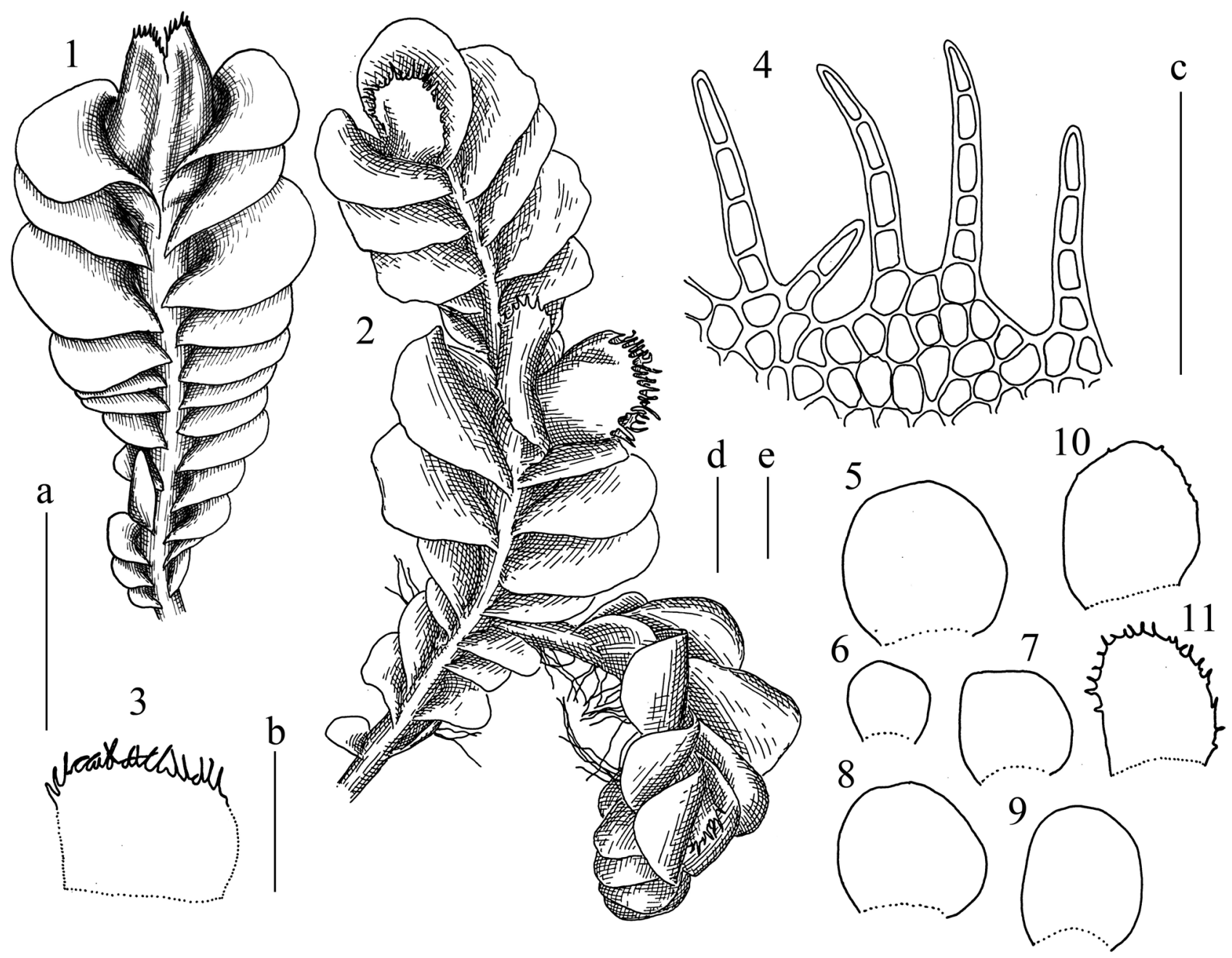

Figure 2 Plagiocbila sichotensis Bakalin et Vilnet: 1, 2 - plant habit; 3 - perianth "lobe"; 4 - perianth mouth armature; 5-9 - leaves; 10, 11 female brachts. Scales: $\mathrm{a}-2 \mathrm{~mm}$. for 1,$2 ; \mathrm{b}-1 \mathrm{~mm}$, for 3 ; c $-200 \mu \mathrm{m}$, for $4 ; \mathrm{d}-1 \mathrm{~mm}$, for $5-9$; $\mathrm{e}-1 \mathrm{~mm}$, for 10, 11. $1-$ from paratype, 2-11 - from holotype (VBGI)

there in the climate variations of the late Pleistocene. Ecologically the taxon may be regarded as acidophilic mesophyte that confined in the occurrence by mesic and partly shaded decaying wood. The requirements of this species seem to be very similar to that of Pedinophyllum truncatum (Steph.) Inoue, widely distributed in virgin broadleaved deciduous and mixed (with conifers) forests of the southern half of Primorye Territory.

\section{DISCUSSION}

Data present in GenBank for Plagiochila sect. Plagiochila are rather poor and, therefore, the morphological comparison with related taxa acquired the higher value in the recognizing of the new species. The sect. Plagiochila is one of the largest sections within the genus and counts 26 extant species (Söderström et al. 2016), with status of some taxa remains questionable. The mentioned list does not include some taxa that probably need to be recognized (like P. satoi S. Hatt., regarded as the synonym of P. porelloides (Torr. ex Nees) Lindenb., cf. So., 2001, etc.). Inoue (1984) recognizes two groups within sect. Plagiochila, with the first one confined to "temperate or cool-temperate region in the Northern Hemisphere" and the second one distributed in "tro- pical regions" (1.c.: 106). These two groups are different in coloration (green to olive green versus often bright brown to yellowish brown), leaf shape (suborbicular to broadly ovate and rounded rectangular usually 1.0-1.5 times as long as wide versus broadly ovate to ovate-oblong and sometimes more than 2 times as long as wide), and leaf margin dentation (entire to shortly dentate versus commonly dentate-ciliate). Another noticeable feature distinguishing 'tropical' bulk of taxa is "relatively large sized leaf cells (usually 25-35 × 25-40 $\mu \mathrm{m}$ in the leaf-middle)" (Inoue 1984: 106).

As it obvious from above placed distinctions, the morphological appearance of Plagiochila sichotensis is belong to the first 'northern' group of the sect. Plagiochila due to the green coloration, totally entire leaves and leaf shape. However it strikingly differs from all recognized taxa known in circumarctic, -boreal and -temperate zones in exceedingly large cells putting the species aside of all known Plagiochila (far larger than relatively large-celled taxa in sect. Plagiochila). The morphology related to 'northern' fraction of sect. Plagiochila taxa is reflected in the cladogram presented here (Fig. 1), where P. sichotensis occupies basal position to northern sect. Plagiochila although not within 'southern' fraction. It should be also noted that $P$. korthalsiana, merged to 

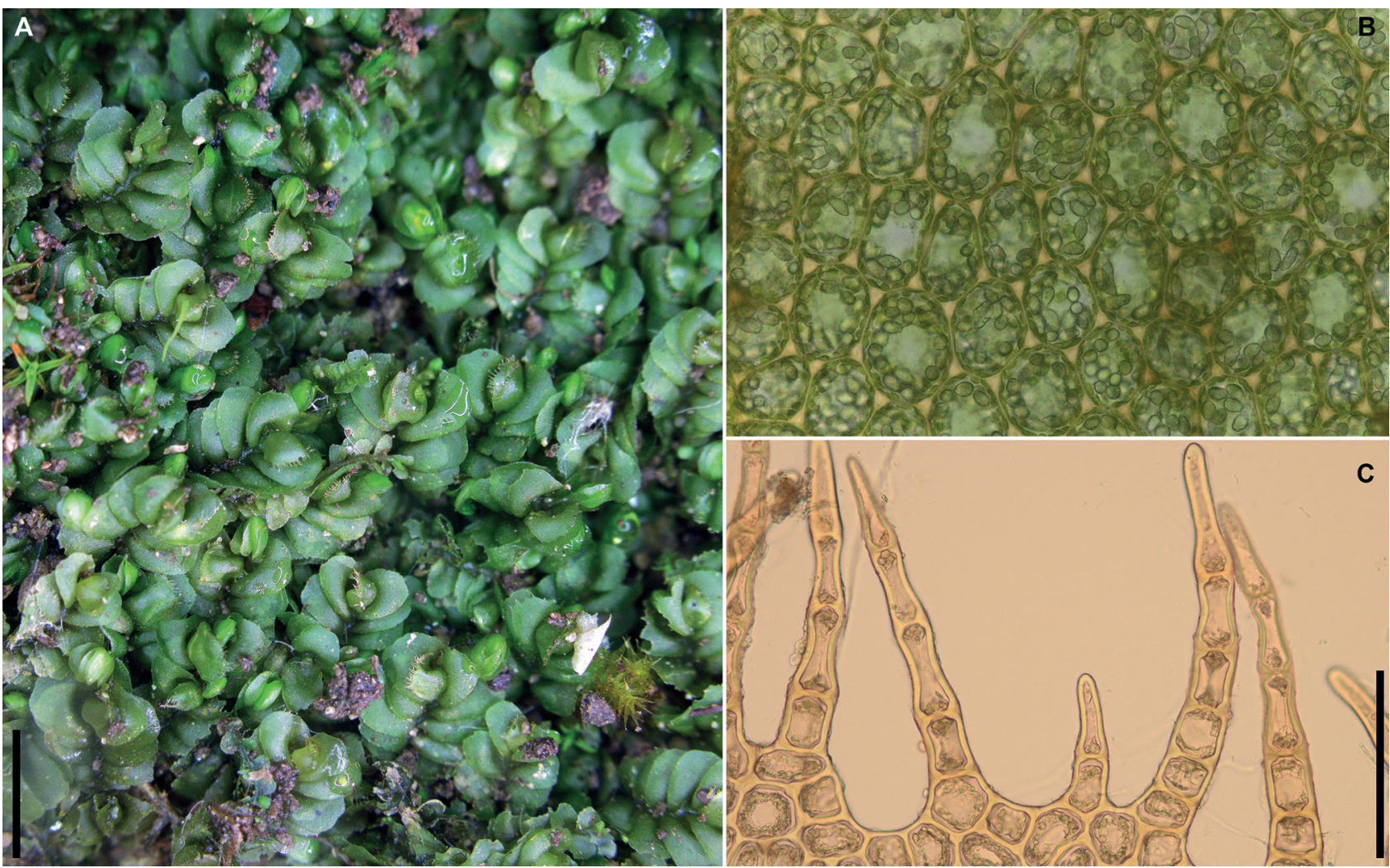

Figure 3 Plagiochila sichotensis Bakalin et Vilnet: A - plant habit; B - midleaf cells; C - cilia along perianth mouth. Scale bars: $3 \mathrm{~mm}$, for A; $100 \mu \mathrm{m}$, for B and C. From holotype (VBGI)

'northern' fraction is not truly morphologically similar to tropical sect. Plagiochila fraction (although distributed in Java and Sumatra) due to pale green to brownish coloration and smaller cell size. Very preliminary the phylogenetic tree may be interpreted as the confirmation that $P$. sichotensis is relatively old taxon of the section that lies 'between' southern and northern taxa fractions of the section. Today the species may decrease the area of distribution since the only female plants were observed in the both known specimens. The plants in known specimens are densely perianthous, but include unfertilized archegonia within perianth only. Therefore it is probably the ability for spreading of this species is limited to distribution by the part of vegetative plants only (that is hardly effective in Plagiochila).

Within regional taxa Plagiochila sichotensis may be probably mistaken with Pedinophyllum spp., Plagiochila satoi and small-sized phases of P. ovalifolia. However, the former differs from Pedinophyllum spp. in ciliate perianth mouth and far large-sized leaf cells. The distinctions from two aforementioned Plagiocbila are more delicate and include invariable entire leaves (even in integrifoliate forms of the both P. ovalifolia and P. satoi it is possible to find at least rudimentary teeth near apices of some leaves), large leaf cells, varying from 33 to $60 \mu \mathrm{m}$ wide in the leaf middle (in two aforementioned taxa the width is less than $30(-35) \mu \mathrm{m}$ in the midleaf) and copiously rhizogenous ventral side of the stem. Another, not so evident feature is more transversely, than in other 'green-colored' Plagiochila sect. Plagiochila, inserted leaves that are more convex in upper halves and, in this respect, resembling leaf shape observed in Pedinophyllum.
Plagiochila sichotensis occurs in far not rare type of habitats: the species was twice collected on decaying wood. This preference to the widely distributed habitat type in the area makes, on the one hand, potential distribution of P. sichotensis very wide, although, on the other hand, increase the number of competitors in suitable habitats. The same factors make difficult the suppositions on probable occurrence of the species in adjacent areas. Due to data in hand (including its rarity in observed habitats) we may suggest the distribution of the species may be confined by the cool-temperate communities in the southern Sikhote-Alin. This type of communities disappears westward as far as in the Khanka lowland and after transformed to more xerophilous prairie-like communities with Quercus and Ulmus as the only trees (besides these prairielike communities are strongly transformed or destroyed due to the human impact). Plagiochila sichotensis may be expected in old-growth mixed forests covering low to middle elevations of East-Manchurian Mountains. However, the probability of such occasion may be low due to strong disturbance of natural vegetation in Manchuria and because of relatively robust phytogeographic difference between Manchurian and Sikhote-Alin flora also discussed before (Fedosov et al. 2016; Bakalin et al. 2017). In general, the discovery of $P$. sichotensis again reconfirms the potential possibility to find several other new hepatic taxa in the contact zone of Circumboreal and East Asian floristic provinces.

\section{ACKNOWLEDGEMENTS}

Authors are deeply indebted to Mr. M.A. Bakalin for drawing preparation and to Dr. Yu.S. Mamontov for helpful 
recommendations in the manuscript preparation. The work was partially supported by the Russian Foundation for Basic Researches (17-04-00018, 15-04-03479).

\section{LITERATURE CITED}

Bakalin V.A., E.V. Butorina \& K.G. Klimova 2017. The Hepaticae and Anthocerotae of Kedrovaya Pad' Nature Reserve - an intact enclave of East Manchurian flora in Russia. Botanica Pacifica 6(1):23-29.

Fedosov V.E., O.Yu. Pisarenko, V.A. Bakalin \& E.A. Ignatova 2016. Venturiella sinensis (Erpodiaceae, Bryophyta) - an addition to the moss flora of Russia. Arctoa 25(2):364-368.

Guindon, S., J.F. Dufayard, V. Lefort, M. Anisimova, W. Hordijk \& O. Gascuel 2010. New algorithms and methods to estimate maximum-likelihood phylogenies: assessing the performance of PhyML 3.0. Systematic Biology 59:307-321.

Hall, T.A. 1999. BioEdit: a user-friendly biological sequence alignment editor and analysis program for Windows 95/98/NT. Nucleic Acids Symposium Series 41:95-98.

Inoue, H. 1984. The genus Plagiochila (Dum.) Dum. in Southeast Asia. Academia Scientific Book Inc., Tokyo, 141 pp. + 76 Plates.

Keane, T.M., T.J. Naughton \& J.O. McInerney 2004. ModelGenerator: amino acid and nucleotide substitution model selection. Available from: http://bioinf.mav.ie/software/modelgenerator/. Last accessed: \#\# Nov 2017.

Kress, W.J. \& D.L. Erickson 2007. A two-locus global DNA barcode for land plants: the coding $r b c \mathrm{~L}$ gene complements the non-coding trn $\mathrm{H}-p s b \mathrm{~A}$ spacer region. PLoS ONE 2, e508.

Pattengale, N.D., M. Alipour, O.R.P. Bininda-Emonds, B.M.E. Moret \& A. Stamatakis 2010. How many bootstrap replicates are necessary? Journal of Computational Biology 17:337-354.

Patzak, S.D.F., M.A.M. Renner, A. Schaefer-Verwimp, K. Feldberg, M. Heslewood, D.F. Peralta, A. Matos de
Souza, H. Schneider \& J. Heinrichs 2016. A phylogeny of Lophocoleaceae-Plagiochilaceae-Brevianthaceae and a revised classification of Plagiochilaceae. Organisms, Diversity \& Evolution 16:481-495.

Renner, M.A.M., M. Heslewood, S.D.F. Patzak, A. SchaeferVerwimp, J. Heinrichs 2017. By how much do we underestimate species diversity of liverworts using morphological evidence? An example from Australasian Plagiochila (Plagiochilaceae: Jungermanniopsida). Molecular Phylogenetic and Evolution 107:576-593.

So, M.L. 2001. Plagiochila (Hepaticae, Plagiochilaceae) in China. Systematic Botany Monographs 60:1-214.

Söderström, L., A. Hagborg, M. von Konrat, S. Bartholomew-Began, D. Bell, L. Briscoe, E. Brown, D.C. Cargill, D.P. Costa, B.J. Crandall-Stotler, E.D. Cooper, G. Dauphin, J.J. Engel, K. Feldberg, D. Glenny, S.R. Gradstein, X. He, J. Heinrichs, J. Hentschel, A.L. Ilkiu-Borges, T. Katagiri, N.A. Konstantinova, J. Larran, D.G. Long, M. Nebel, T. Pôcs, F. Felisa Puche, E. Reiner-Drehwald, M.A.M. Renner, A. Sass-Gyarmati, A. Schâfer-Verwimp, J.G.S. Moragues, R.E. Stotler, P. Sukkharak, B.M. Thiers, J. Uribe, J. Vâna, J.C. Villarreal, M. Wigginton, L. Zhang \& R.-L. Zhu 2016. World checklist of hornworts and liverworts. PhytoKeys 59:1-828.

Stamatakis, A. 2006. RAxML-VI-HPC: Maximum likelihood-based phylogenetic analyses with thousands of taxa and mixed models. Bioinformatics 22:2688-2690.

Tamura, K., D. Peterson, N. Peterson, G. Stecher, M. Nei \& S. Kumar 2011. MEGA 5: Molecular evolutionary genetic analysis using maximum likelihood, evolutionary distance, and maximum parsimony method. Molecular Biology and Evolution 28:2731-2739.

White, T.J., T. Bruns, S. Lee \& J. Taylor 1990. Amplification and direct sequencing of fungal ribosomal RNA genes for phylogenetics. In: PCR protocols: a guide to methods and applications (M.A. Innis, D.H. Gelfand, J.J. Snisky \& T.J. White, eds.), pp. 315-322. San Diego. 